\title{
IDEOLOGIES AND IMPOLITENESS STRATEGIES IN ONLINE ETHNO-RELIGIOUS CONFLICT AMONG NIGERIANS
}

\author{
Temitope Michael Ajayi \\ Ganiu Abisoye Bamgbose
}

\begin{abstract}
Nigeria is a multilingual country comprising peoples of different ethnic, political and religious inclinations, hence the incessant ethno-religious conflicts that lace her trajectory. Different scholarly works have examined ethno-religious conflict in the Nigerian space from the religious, sociological, historical and political perspectives. However, little attention has been given to the phenomenon from the linguistic perspective. This study, therefore, drawing inputs from van Dijk's Critical Discourse Analysis and Culpeper's Impoliteness Theory, investigates how Nigerians deploy language in engaging in ethno-religious conflict as evident in their online comments on issues of national interest in the country. Different online comments and reactions of Nigerians to four recent national issues - Apostle Suleman's alleged 'sex scandal', the Southern Kaduna killings in Kaduna, the Yoruba-Hausa crisis in Ife, Osun State, and the issues surrounding the arrest, detention and clamour for the release of Nnamdi Kanu, a strong agitator for the Biafra State, as reported by three online platforms, Sahara Reporters, Vanguard Newspaper and Nairaland.com are purposively selected as data for this study. The findings of the study reveal elements of they (them) versus we (us) ideology and different forms of impoliteness strategies permeate the discourse of online ethno-religious conflict among Nigerians. This is a development that portends a bad omen for the continued peace and unity of the country.
\end{abstract}

Keywords: Ethno-religious conflict, van Dijk Critical Discourse Analysis, Culpeper's Impoliteness theory, Nigeria 


\section{Background to the Study}

Nigeria is one of the countries in the world populated by people who are diverse in their linguistic, religious, cultural, ethnic and ideological stand-points. The fact that there are many languages in the country attests to her cultural and ethnic diversity. In the area of religion, Nigeria ranks among the most religious countries in the world, as, apart from the two major religions officially recognised by the government of the country, there are several other religions and religious groups in the country. This multilingual, cultural, ethnic, religious and ideological nature of the country is perhaps the reason her trajectory has been laced with myriads of conflicts right from inception. The afore-submission becomes compelling in view of the countless ethno-religious, cultural and linguistic conflicts the country has witnessed between her independence in 1960 and now (2017). Some of these unfortunate conflict-turn crises include the Kano riot of 1953, the 1967 to 1970 Civil War, the incessant cases of ethno-religious killings in the North (e.g. the Southern Kaduna killing of 2017), and the Yoruba-Hausa conflict in Ile Ife in 2017, among others. All these are worrisome developments that have in one way or the other threatened the 'fragile' peace and unity of the country.

In reaction to this ugly trend and scenario, several scholarly works from the sociological, religious and historical perspectives have been carried out, both within and outside the country. However, not so much attention has been given to the study of ethno-religious conflict in Nigeria from a linguistic point of view. This study is a crucial intervention in this regard, as it demonstrates the fact that, even when the various ethnic and religious groups in the country do not engage in physical attack on one another, there are elements of subtle hatred, indignation and suspicion among them, a development that portends a bad omen for the national integration of the country.

In this study, we aim to examine:

- the impoliteness strategies and discursive moves employed by actors in social media ethno-religious conflict in Nigeria;

- how religious ideologies are employed and perceived as weapons of word war on the social media among Nigerians;

- how ethnic ideologies are employed and perceived as weapons of word war on the social media among Nigerians;

- the implications of the use of the social media as a platform for ethno-religious conflict in Nigeria for growth, national unity and development.

\section{Conceptualising Ethno-religious Conflicts}

In his conceptual definition, Weber (1971) opines conflict is 'any action that is oriented intentionally to carry out actor's own wish against the resistance of the other party or parties'. To this scholar, conflict ensues when an individual or a group deliberately initiates an action or move that the other party or parties consider(s) inimical to their interest. In Coser's (1956) conception, 'conflict is a struggle over status, power and 
scarce resources in which the sole aims of the parties involved are not only to gain the desired value but also to neutralize, injure or eliminate rivals'. Here, Coser sees conflict as having destructive and devastative tendencies. It is a phenomenon that revolves round struggle and unhealthy rivalry for things or objects to which individuals or groups attach importance. Osaghae (2011) notes that these things or objects can exist in the material and non-material forms. The material objects or things could comprise scarce resources such as money, jobs, services, political positions and promotion in both private and public establishments. The non-material objects, on the other hand, include culture, religion and language. As submitted by Ajayi and Buhari (2014:15), a conflict situation ensues when two or more individuals could not agree over an issue. Thus, in a conflict, every party involved seeks to achieve certain objectives such as secure territory, security, access to market, among others (Ajayi and Buhari, 2014: 140). From all these definitions, it suffices to say conflict, although not to be desired, is an essential part of every human society.

Adetoye and Omilusi (2015), in their discussion on ethno-religious conflict, argue that ethnic conflicts are not only restricted to conflicts between members of different groups (inter-group conflict), but can also be observed between or among members of different segments or sub-groups of the same group (such as intra-ethnic conflicts and communal conflicts). Osaghae (2011) observes ethnic conflicts often manifest in form of a survival-of-the-fittest contest which often engenders violence. Ayantayo (2005) claims religious conflict is birthed 'when each of two religious persons occupying the same religious space claims a monopoly of religious truth' and since they cannot hold the same (religious) truth at the same time, there is bound to be opposition, friction, acrimony, incompatibility, hatred, hostility, clash and ultimately conflict or war between them.

Drawing inspiration from the view of Ayantayo (2005), Adetoye and Omilusi (2015) define inter-religious conflict as such that involves disagreement between two religious persons with respect to who or who is not holding absolute religious truth. According to them, this usually manifests when members of religions are engaged in argument which often goes with bickering, controversy, demonstration, debate or squabble over religious beliefs and practices. Jega (2002:35) describes ethno-religious conflict as a situation in which the relationship between members of one ethnic group and another, or generally amongst ethnic groups, in a multicultural polity such as Nigeria, is characterised by lack of cordiality, heightened mutual suspicions and fears, quarrelsomeness and a tendency towards violent confrontations. In his opinion, any community or polity experiencing ethno-religious tension is in a precarious state of volatility, insecurity and instability. In such society, if care is not taken to reverse or address the situation, any minor imbroglio between or among the members can result in total breakdown of law and order. 
From the above, we conceive of ethno-religious conflict as such that involves disagreement, clash and friction, which could be violent or non-violent, between or among individuals or groups belonging to different ethnic or religious camps. Their differences could evolve as a result of their divergent ideological, religious, cultural or linguistic differences.

\section{Previous works on Ethno-religious Conflict in Nigeria}

Adetoye and Omilusi (2015) examine the impacts of ethno-religious conflicts on democracy in Nigeria from a socio-political perspective. The scholars observe Nigeria is 'a melting pot of ethnic nationalities, class, regions, religions and other sociocultural markers', hence the pluralistic nature of the country. According to them, the pluralistic nature of the country has in a way done more harm than good to her development, particularly in her democracy. This is because, as submitted by these scholars, the political class has exploited and employed ethnicity and religion as 'symbols of mobilization and instruments of negotiation for patronages and sharing of national resources' (p. 1). Idahosa (2013) explores ethno-religious conflict and peace building in Nigeria, with particular reference to the situation of Jos, Plateau State, Nigeria. He paints a graphic picture of the ethno-religious crisis situation in Jos, noting in particular the incessant cases of conflict between the majority Christian indigenes and minority Muslim settlers in the city. In his opinion, while every effort by the government at all levels to put a permanent end to this unfortunate situation has been ineffective, there has not been any serious move on the part of the warring groups to address it, hence the high spate of destruction of lives and properties witnessed in the city.

Fawole and Bello (2011) equally attempt a socio-political investigation of the impact of ethno-religious conflict on Nigerian federalism. Of central concern to the discussion of this scholar is how the issue of sharing the national wealth of the country among its component units has been a hydra-headed problem. Fawole and Bello (2011) conclude ethno-religious conflict has retarded true federalism in Nigeria, as ethno-religious bigotry which manifests in forms of language assertion, cultural autonomy and chauvinism permeates and contaminates social relations among its component units.

Sule (2012) examines the role of the mass media in ethno-religious conflicts, particularly as often witnessed in the Northern part of Nigeria and its implication for national development in the country. From a philosophical-religious perspective, the study critically examines news reports and analyses, editorials, advertorials and special columns' contents of some newspapers and news magazines and concludes the mass media contributes immensely to the escalation of conflicts in the Northern region of the country, a development that has negatively affected the socio-economic development 
of the region. He further reports that, even in situations where conflicts arise as a result of some other factors, they are usually given religious colourations, thereby making them very difficult and highly problematic to handle.

However, as pointed out earlier, none of these studies has given attention to the subtle inter-ethnic, political and religious word war fought among the various ethnic groups in the country, particularly on the social media. Meanwhile, observation has revealed that, even when there appears to be the absence of physical crises among the various ethnic, religious and political groups in the country, the unity and national integration of the country is still threatened as elements of hatred and indignation characterise the social and linguistic interaction of these groups, who often wait for the occurrence of issues of national, ethnic, political and religious interest to manifest. While existing studies have given attention to actual ethno-religious and political conflicts in the country, this study is significantly different in that it draws attention the fact that the absence of physical, political, religious or ethnic crises or conflicts in the country is not tantamount to absolute tranquillity and harmony. This, if not addressed, is a major threat to the nationhood of Nigeria.

\section{Theoretical and Analytical Tools: van Dijk's Critical Discourse Analysis and Culpeper's Impoliteness Theory}

Critical Discourse Analysis (CDA) is mainly concerned 'with analyzing opaque as well as transparent structural relationships of dominance, discrimination, power and control as manifested in language' (Reisigl and Wodak, 2009). Commenting on the efficiency of CDA, Rashidi and Souzandehfar (2010) remark that CDA is the right place to perform autopsy on discourse, either written or spoken, so as to uncover the ideologies underlying it. For its suitability, van Dijk's (2004) model of CDA is adopted for analysis in this study. Van Dijk's (2004) framework consists of two main discursive strategies of positive self-representation (semantic macro-strategy of in-group favouritism and 'negative other-representation (semantic macro-strategy of derogation of out-group) which are materialized through some other discursive moves such as actor description, authority, burden (Topos), categorization, comparison, consensus, counterfactuals, disclaimer, euphemism, evidentiality, example/'illustration, generalization hyperbole, implication, irony, lexicalization, metaphor, self-glorification, norm expression, number game, polarization, Us-Them, populism, presupposition, vagueness, and victimization. Above are 27 ideological strategies among which the fundamental dichotomy of 'self positive-representation' and 'other negative representation' stand out. 


\subsection{Culpeper's Impoliteness theory}

In the opinion of Mills (2003: 121), much research has been done on politeness all over the world; however, not much could be said to have been done on impoliteness. According to her, the aforesaid might be as a result of the fact that in most studies, conversation is viewed as a phenomenon that follows the contracts of communication and is harmonious and balanced between the speakers. But there are instances where speakers attack rather than save each other's face in conversations, hence the concept of impoliteness and the need to give scholarly attention to it.

According to Locher and Bousfield (2008: 3), "Impoliteness is a behaviour that is faceaggravating in a particular context". This definition sees impoliteness and rudeness as synonymous. In reaction to this definition, Culpeper (2008) makes a distinction between impoliteness and rudeness. According to Culpeper, both impoliteness and rudeness are "inappropriate and negatively marked" behaviour. However, the difference between them is that, while impoliteness is intentional, rudeness is unintentional negative behaviour. Therefore, impoliteness is something that is caused intentionally. This position of Culpeper is a sharp contrast to the one maintained by Terkourafi (2008: 61-62) who argues that while impoliteness is unintentional, rudeness is intentional. Culpeper's impoliteness theory is adopted to analyse elements of impoliteness in our data.

Culpeper $(1996,2008)$ opines that impoliteness is a linguistic behaviour aimed at attacking the face of another. He classifies impoliteness into two different categories: inherent impoliteness and mock politeness or banter. According to him, there are acts that innately threaten one's face regardless of the context of the act; this is called inherent impoliteness. On the other hand, impoliteness that stays on the surface and is not intended to insult anyone is called mock impoliteness (Culpeper 1996: 4). He also outlines five impoliteness super-strategies which are obviously opposites of Brown and Levinson's (1987) politeness super-strategies. Culpeper (1996) says: "Instead of enhancing or supporting face, impoliteness super-strategies are a means of attacking face" (p. 8). He describes the five super-strategies as follows: Bald on record impoliteness - the FTA is performed in a direct, clear, unambiguous and concise way in circumstances where face is relevant. This strategy is different from Brown and Levinson's Bald on record in that, for Brown and Levinson, Bald on record is a politeness strategy in fairly specific circumstances, positive impoliteness - the use of strategies designed to damage the addressee's positive face wants, negative impoliteness - the use of strategies designed to damage the addressee's negative face wants, sarcasm or mock politeness -the FTA is performed with the use of politeness strategies that are obviously insincere, and thus remain surface realizations and withhold politeness - the absence of politeness work where it would be expected. For example, failing to thank somebody for a present may be taken as deliberate impoliteness (Culpeper 1996: 8-9). 
Culpeper (1996) also spells out strategies for negative and positive impoliteness. These strategies are as follows:

\section{Negative impoliteness output strategies:}

- Frighten - instill a belief that action detrimental to the other will occur;

- Condescend, scorn or ridicule - emphasize your relative power. Be contemptuous. Do not treat the other seriously. Belittle the other (e.g. use diminutives);

- Invade the other's space - literally (e.g. position yourself closer to the other than the relationship permits) or metaphorically (e.g. ask for or speak about information which is too intimate given the relationship);

- Explicitly associate the other with a negative aspect - personalize, use the pronouns 'I' and 'you';

- Put the other's indebtedness on record.

\section{Positive impoliteness output strategies:}

- Ignore, snub the other - fail to acknowledge the other's presence;

- Exclude the other from an activity;

- Disassociate from the other - for example, deny association or common ground with the other; avoid sitting together;

- Be disinterested, unconcerned, unsympathetic;

- Use inappropriate identity markers - for example, use title and surname when a close relationship pertains, or a nickname when a distant relationship pertains;

- Use obscure or secretive language - for example, mystify the other with jargon, or use a code known to others in the group, but not the target;

- Seek disagreement - select a sensitive topic. Make the other feel uncomfortable - for example, do not avoid silence, joke, or use small talk;

- Use taboo words - swear, or use abusive or profane language;

- Call the other names - use derogatory nominations.

Culpeper (2011) sees impoliteness as a multi-disciplinary field of study that has a link with scientific fields such as psychology, sociology, conflict studies, and media. It is thus, a complex and multi-dimensional subject to study (Kuntsi, 2012).

The combination of these theories helps reveal how linguistic tools are employed by different groups, ethnic, political and religious, for instance, in Nigeria to construct identities, ideologies and perception about others in four events of national interest in the country. 


\section{Methodology}

The data for this study are online comments and reactions of Nigerians on four most recent happenings in the country that have generated heated reactions and counter reactions among Nigerians. These events are the recent Apostle Suleman's alleged sex scandal with the headline I stand with Apostle Suleman with a Canadian-based female musician, the Southern Kaduna killing in the North, the Yoruba-Hausa crisis in Ile Ife and issues surrounding the arrest and detention of Nnamdi Kanu, a force to reckon with in the clamour for the creation of Biafra by the Igbo people in the country, all in 2017. These four events have been purposively selected among many other current ethnoreligious issues that have sparked off serious controversies on the Internet among Nigerians because of their popularity and the fact that they cut across the three major ethnic groups in the country. The online comments and linguistic reactions that constitute our data are captured on three popular news and information sites- the Vanguard newspaper online platform, Sahara Reporters and Nairaland.com. The first two are popular newspaper outlets in the country that enjoy unprecedented readership and patronage from a lot of Nigerians, hence it is believed any information got on their platform is authentic; while the third one is a platform that gives many Nigerian youths the opportunity to react to and comment on social and political happenings in the country. The platform has gained much readership in the country, especially among youths, because apart from giving them day-to-day information about the sociopolitical developments in the country, it is a site that readily serves as a veritable source of job information for the teeming unemployed Nigerian youths. Data are subjected to van Dijk's Critical Discourse Analysis and Culpeper's Impoliteness Theory.

\section{Data Presentation and Analysis}

\section{Elements of They (them) versus We (us) Ideology in Online Ethno-religious Conflict among Nigerians}

Elements of They (them) versus We (us) ideology permeate the posts and replies to posts of the individuals whose posts are captured for analysis in this study. These pronouns, they/ them on the one hand, and we/us, on the other, represent the conflicting groups- religious and ethnic in the country. These posts and their analysis are presented below:

\section{Example 1}

The posts here revolve round the issue of sex scandal Apostle Suleman is purportedly involved in with a Canada-based female musician.

\section{Excerpt 1}

Background Post: Governor Ayodele Fayose of Ekiti State has described the 
Ajayi \& Bamgbose: Ideologies and Impoliteness Strategies in Online Ethno-Religious Conflict Among Nigerians

$\overline{\text { adultery allegation against Apostle Johnson Suleman of the Omega Power Ministry by }}$ one Miss Stephanie Otobo as a "high-level conspiracy meant to destroy the integrity of the pastor and silence his critical and principled voice of truth and dissent in a nation fast becoming a one-party state".

A number of discursive strategies are employed in the excerpt above to foreground identities and ideological stances. First of the tools is the disclaimer move which is employed by a PDP (People Democratic Party) chieftain and governor, Ayodele Fayose, to vindicate the accused pastor of the alleged rape. It is evident however that beneath the vindication is a political motive of castigating the ruling party, APC (All Progressives Congress) through the discursive tool of example/illustration as reflected in the nominal group 'a nation fast becoming a one-party system' which is a reference to the political party in power in Nigeria. In substantiating this ideological stance, Fayose employs the associate the other with negative aspect impoliteness sub-strategy in identifying the ruling party with the act of oppression and repression and ultimately truth subversion. This ideological stance is also evident in his statement, as presented in Excerpt 2 below:

\section{Excerpt 2}

"This was the same way they tried to drag the General Overseer of the Redeemed Christian Church of God (RCCG), Pastor Enoch Adejare Adeboye, in the mud. The whole world was aghast at how they insulted and ridiculed the highly-revered RCCG General Overseer. But for the outcry from all over the world, they almost bundled out Pastor Adeboye from his position as RCCG General Overseer and could have even arrested the General Overseer of Winners' Chapel, David Oyedepo".

As a way of further defending the Apostle, in the post above (Excerpt 2), Fayose reminds the readers of how similar political strategies were orchestrated by some undisclosed members of the political class to malign the image of two respected pastors in the country: Adeboye and Oyedepo. As seen in the first excerpt, this text credited to Governor Fayose of Ekiti State, Nigeria, to save the face of the Nigerian pastor, can be seen as a political strategy to cast aspersion on the ruling party whose administration has been greatly condemned by him. This is evident with the use of the us-them discursive move as the third person (subject, plural) personal pronoun is repeated three times in the short quote. There is also the complementary use of the tool of presupposition which will make a sympathetic reader conceive of the ruling party (APC) as one which haunts innocent people, especially highly placed Nigerians, like pastors, as the number game played with name calling in the excerpt shows. From the submission of Fayose, one is compelled to infer that the State, presided over by a nonChristian president, is biased in its dealing with religious matters, especially as it relates to Christians and Christianity. This submission is reinforced by his position in his 
statement presented in excerpt 3 as follows:

\section{Excerpt 3}

"Should it not interest Nigerians and the international community that up till today, none of those herdsmen that killed thousands of Nigerians in Benue, Enugu, Delta, Ogun, Plateau and Kaduna States have been arrested? Even those arrested in connection with the murder of the Abuja-based female pastor, Eunice Elisha, have been released".

This statement, which is also credited to the most reported Nigerian governor in media in the last two years, is also laced with a subtle and implicit condemnation of the ruling government in Nigeria, given the game played with number in terms of the reference to 'thousands of Nigerians' purportedly killed by herdsmen across the listed states. There is, therefore, the presupposition that the ruling government of Nigeria is a biased one that is sectional in their provision of security for the citizenry.

\section{Excerpt 4}

Post A: People are religiously blind. They claim to worship God when they actually worship their fellow being. Though I exempt the western world where there seems to be wisdom. In Nigeria, even if you call yourself god, before looking back, you'd find that people have been worshiping you! Yes, those who are religiously blind. Must you allow these evil prophets to destroy all your lives before you realize that they're devils? One of them set some of his church attendants ablaze the other time, yet you defended him. Another impregnated almost half of the ladies in his church including married women, you defended him still. This is another one, and Buhari is being accused. Pls how is Buhari connected with this matter? I'm not denying there are good pastors.

\section{Excerpt 5}

Post B: 'Just bcos the apostle raised a voice against Fulani herdsmen now they are accusing and trying to bring his name to $d$ mud,,,shame to Nigeria....victory at last for our ordained apostle'

The writer of this Post A employs the associate the other with a negative aspect negative impoliteness sub-strategy, describing Fayose, a Christian and other Christians who have displayed their loyalty to Apostle Suleman, as individuals who have shifted their attention from worshipping God to worshipping men, pastors. The author wants to dissociate himself from this practice which, according to him, denotes 'religious blindness'. Apparently, the writer of this post does not share the same religious ideological position with those individuals whose faces he attacks with the post. In his/her response to A's post, B equally employs the same impoliteness strategy to accuse some unnamed individuals who are believed, to either be Muslims or Northerners, who are in support of the nebulous activities of some Fulani herdsmen in 
Ajayi \& Bamgbose: Ideologies and Impoliteness Strategies in Online Ethno-Religious Conflict Among Nigerians

the country as being the masterminds of the ordeal of Apostle Suleman, whom he/she believes is a man ordained by God. The author of this post (B) believes Apostle Suleman's condemnation of the activities of these herdsmen is the reason he is being 'framed up' in the sex scandal.

These accusations and counter-accusations are against the backdrop of the fact that the present administration has come under serious criticism from Nigerians, particularly those from the Southwest and Southeast regions of being biased in her political appointments, as it is widely claimed that the administration is largely made up of men and women from the Northern region, particularly the Hausa-Fulani group where the president hails from. It is, therefore, taken that those who are against 'the man of God' are agents of the State who are protecting the Hausa-Fulani agenda.

\section{Excerpt 6}

Why Fayose involved himself in dis saga? His usual and inborn character of always being opposite of the majority will ends him nowhere even in his party. Let's wait and see what is going to happen between the two lovers. When it comes to love affairs few people are exempted no matter the position. Just trust yourself no one is a saint.

The author of this post constructs his/her ideological stance with the discursive move of actor description as s/he bluntly describes Fayose with the noun phrase, his usual and inborn character of always being opposite of the majority. The author further employs the tool of metaphor to derogatorily refer to the accused pastor and the accuser as lovers to further discredit Governor Fayose's affiliation to him (the accused pastor). There is, therefore, the presupposition that the author has an allegiance and affinity to the Federal Government, given his reference to Fayose as being anti-the ruling party.

\section{Excerpt 7}

Education does not play any roles in many people's life! Yes, those who are religiously blind. Must you allow these evil prophets to destroy all your lives before you realize that they're devils? One of them set some of his church attendants ablaze the other time, yet you defended him. Another impregnated almost half of the ladies in his church including married women, you defended him still. This is another one, and Buhari is being accused. Pls how is Buhari connected with this matter? I'm not denying there are good pastors. But when you see the devilish ones, say it.

This post, in its opening and middle part, appears to be a simple and innocent piece of advice against religious extremism, especially in terms of unquestionable loyalty to pastors. However, the latter part reveals that the number game of reference to some bad pastors is deliberately employed to gather momentum for the accusative question which borders on alleged Buhari's involvement in the religious saga in the country. There is, 
therefore, the presupposition that this writer aligns with Buhari as a leader who is disinterested in the victimisation of religious leaders. It can also be inferred from the post that the author has religious bias against Christianity, considering the various examples cited by him/her of pastors who had been involved in one ignoble act or another at different times. If not, he/she could have cited examples of Muslims and particularly Muslim clerics who are also guilty of the allegations pointed out in his/her post.

\section{Excerpt 8}

Post C: I pity those behind all this scam, because God of vengeance will fight for his servant, and all those behind this fake lies will receive their reward and it will be too disastrous.

\section{Excerpt 9}

Post D: Who determine man of God.is it Fulani that asked him to go into relationship or Buhari that connected two of them.too much hypocrisy in religions nowadays.

The author of post $\mathrm{C}$, making reference to his Christian ideological belief in God to defend His own, employs the frighten the other negative impoliteness sub-strategy to instil fear in the people believed to be behind the predicament of the Apostle (Suleman). He/she threatens them-'those behind this scam'- that something disastrous awaits them from God who would reward them for their lies and falsehood against the man in the eye of the storm. The author of Post D, apparently not in agreement with the submission of author $\mathrm{C}$, employs the seek disagreement negative impoliteness substrategy to counter his/her position. He also employs the condescend, scorn or ridicule the other negative impoliteness sub-strategy to query the idea of some individuals calling their religious leaders men of God. From his/her question, 'is it Fulani that asked him to go into relationship or Buhari that connected the two of them?', it is clear that he/she associates the Apostle with the scandal.

\section{Excerpt 10}

Post E: mumu that's the only class $u$ belongs to, $u$ are always In support of evil things what a pity. some 1 in the name of god dupe his follower and spend to prostitute, and he is having a mad dog support good.

In Post E, the author employs the use taboo words positive impoliteness substrategy to attack the faces of the supporters of Apostle Suleman as well as those who share his religious ideology. This is apparent in his reference to them as ' $m u m u$ ' fools and 'mad dogs'. In the same post, he employs the associate the other with the negative aspect impoliteness sub-strategy in accusing them of supporting 'evil things'. Given the ethno-religious polarisation of the country, it is difficult to submit the authors of 
Ajayi \& Bamgbose: Ideologies and Impoliteness Strategies in Online Ethno-Religious Conflict Among Nigerians

these conflicting posts share the same ethnic or religious perception. One can argue that those in support of Apostle Suleman are either Christians or non-Hausa while those against him are either Muslims or Hausa-Fulani.

\section{Example 2}

This revolves round the Southern Kaduna killing in Kaduna earlier in 2017.

\section{Excerpt 11}

Open your eyes Jan 26, 2017 This not a religious crisis but with inciting comments and propagander it could become one. .it's got nothing to do with president Buhari. This started long before he came into power, point to note ...it's an invasion! They kill both Christians and Muslims. Best we look above Religious sentiments and stop thinking like Children that cant see the bigger picture. We need to come together as one, Both Christians and Muslims to fight this. Good Day Nigerians!

This excerpt has the discursive move of a disclaimer as the writer attempts a vindication of President Muhammadu Buhari from the accusation regarding his involvement in the activities of the insurgents in Nigeria. With the generalisation achieved by mentioning the two major religious groups in the country, Christians and Muslims, s/he implies that the activities of the insurgents do not suggest loyalty to any religion. He, therefore, constructs them as enemies to all faithful with the polarising pronoun, they. The metaphorical use of the word 'children' to mean people with no insight can also be considered as ridicule or condescend the other positive impoliteness sub-strategy purposefully employed to castigate those who consider the insurgents' activities as a religiously motivated one even though this castigation is made subtle by the inclusive use of we.

\section{Excerpt 13}

Greatman what has Christians not done for peace to reign. A christian will NEVER raise his hand on an unbeliever talk more of his brother or neighbour. Christians has always shown these Muslim love but what do they get in return? If those people killed you knw one of them thats when you know how painful it is. I have come to understand that themuslims just don't want peace.

Evident in this excerpt is the discursive move of us-them dichotomy. The writer gathers momentum for his/her conclusion that Muslims are people who do not want peace with the lexicalised emphasis of never and the implied reference to Muslim(s) as unbeliever(s).The determiner these as found in the noun phrase these Muslims is also a lexical pointer to the clear dichotomy constructed by the author of this post between the faithful of the two religions (Islam and Christianity). In his/her ideological stance, 
he/she projects Muslims as peace shooters who repay Christians with violence in spite of the love shown to them (by Christians). This is a deliberate deployment of associate the other with negative aspects positive impoliteness sub-strategy to ideologically construct a 'terrorist' identity for Muslims as well as their religious beliefs.

\section{Excerpt 14}

Yes. Islam is the perfect Religion of Allah, the creator of the heaven and earth and what is in between them. While Muslims are humans following the religion of Islam, and they are not perfect, they make mistakes, they might misinterpreted things, and they blame should go to them personally and not to Islam. Thank $u 4$ reading!

In the post above, there is the use of a disclaimer device by the writer as a strategic discursive move to defend his/her ideological stance that Islam is a perfect religion which embraces peace. In pursuing this ideological stance, s/he separates the religion from those who practise it, Muslims, who are fallible like every other human being on earth. S/he also employs the discursive tool of actor description to describe Allah as the supreme God and links this religion to Him as a way of establishing that Islam is perfect like its creator, Allah, even if Muslims might be deficient.

\section{Excerpt 15}

Islam is created by the devil. They don't value human life at all. This is pathetic and painful. Thank God for the life of Christians who truly fear God and value human life irrespective of where you hail from. Christianity accommodate anybody be he Muslim or pagan but the opposite is the Islam. I don't know why a reasonable human being will be living together with Fulani Jihadist, They are evil and unforgiving like their Grandpa from Daura.

In this post, the author consciously employs the use of associate the other with negative aspect positive impoliteness sub-strategy to attack Islam as a religion and Muslims generally. This author makes a clear dichotomy between Islam and Christianity, portraying Islam as a devilish religion through the discursive move of comparison. A clear us-them boundary is created between the Christians and the Muslims in Nigeria with the use of the third person plural pronoun, they, to refer to Muslims. There is evidently the use of the discursive move of self-glorification as the author portrays Christians as 'God-fearers' and god-fearing, and Muslims as otherwise. The author equally subtly employs the ridicule the other negative impoliteness substrategy where s/he reduces Fulani Jihadists to non-humans 'I don't know why a reasonable human being will be living together with Fulani Jihadist' who no sane human should interact with. The author's reference to Daura in his/her post equally has some pragmatic imports. Buhari, Nigeria's president, is from Daura, hence there is a link between him and the 'unforgiving' Fulani Jihadists who promote Islamic ideologies. To the author of this post, Christianity is ideologically peaceful, while Islam 
Ajayi \& Bamgbose: Ideologies and Impoliteness Strategies in Online Ethno-Religious

Conflict Among Nigerians

is ideologically violent.

\section{Excerpt 16}

No, my friend, u moat have encountered the so-called Muslims who does not understood the teaching of Islam and made one mess then $u$ are judging the whole Islam by them. It is mentioned in the Qur'an that, " whosoever kill an innocent soul it is as if he had kill the whole mankind and who whosoever save a soul it is as if he had save the whole mankind" take the correction pls. U can ask your questions. Anything about Islam. Thank $u$.

The writer of this post employs the counterfactual tool to debunk the claim of the earlier comment on Islam as being a devilish religion. The metaphorical use of the noun phrase, my friend, is a discursive strategy at endearing him/herself to the writer of the earlier post as a way of creating a friendly atmosphere for his/her argument. The tool of evidentiality, therefore, follows as the writer makes reference to the holy book of Islam which forbids Muslims from killing innocent souls. He, therefore, tactically saves the face of Islam as a peaceful religion from possible misbehaviours of Muslims.

\section{Example 3}

This centres on the arrest, detention and the clamour for the release of Nnamdi Kanu, a Biafran agitator from the East

\section{Excerpt 17}

'The war is over and won by Republic Of Biafra. The north has conceded war defeat and ready to go. Their people from west and north working for the bandits that call itself federal government to leave Republic Of Biafra now'

The secession move of the Eastern Nigerians is a long standing one, dating back to the mid 1960s. This effort has, in few years back, been resuscitated by the effort of a young man called Nnamdi Kanu, who has been imprisoned by the Nigerian government on the grounds of being a threat to national security. This strong will to secede is discursively, ideologically and optimistically constructed by the author of the post above, using the discursive moves of self-glorification and hyperbole. He glorifies the Biafra as the winner of a war yet to break out. The us-them dichotomy between the Biafran agitators and the Nigerian State is sharply constructed with the noun phrase, 'their people from west and north' working for the 'bandits that call itself federal government'. In the post, the author employs the call the other names (derogatory nomination) negative impoliteness sub-strategy, to refer to the Westerners and Northerners in the country who are not in support of the realisation of the Biafra dream as 'bandits'. This reveals a strong will towards self-actualisation and a pronouncement of a different national identity. 


\section{Excerpt 18}

You see how stupid you all are in the IPOB? How long will you continue to shout "if you don't release Kanu this and that will happen", just how long? What have you not said and yet the poor silly boy continues to languish in Kuje prisons? The only thing you have not done is to go and slam open the prisons and let him out, that is all you have not done. And if you were brave enough, that small yahoo yahoo boy is not brave at all...

The author of this excerpt also bluntly and aggressively consolidates on the $u s$ them dichotomy established by the first author (in Excerpt 17). This is foregrounded with the pronoun phrase you all which is used to refer to one of the bodies agitating for Biafra, IPOB. The metaphorical noun phrases, poor silly boy and yahoo yahoo boy which are derogatory names used to refer to the lead agitator for Biafra, Nnamdi Kanu, is evidently a rhetorical device to make a mess of the secession effort of the Biafrans.

\section{Excerpt 19}

Whether you like it or not zoo Nigeria is doomed and Biafra must become a reality. The joke is on you for not reading the hand-writing on the wall-MENE, MENE ...

A critical perusal of the post above reveals the writer is pro-Biafra. This is evident in his/her strong belief in the actualisation of Biafra. This s/he achieves not just directly but also by derogatorily and metaphorically constructing Nigeria as a zoo. The meaning implication of this is an implicit reference to Nigerians as a people less than higher human beings. And since they (the Biafrans) are human beings, they cannot continue to occupy the same space with Nigerians who are 'animals'. A clear dichotomy is, therefore, discursively created between these two peoples who occupy the same geographical space.

\section{Excerpt 20}

Blah blahblah, fucking biafraud monkeys go and die or jump in the freaking Lagos lagoon. Fucking retards

This short excerpt is also loaded with details as the discursive move of implication helps interpret 'blah blahblah' as fruitless or unproductive noise towards the actualisation of a sovereign state by the Biafrans. The writer of the post is not mincing words in threatening the faces of the Biafran agitators by referring to them in unprintable words. The coinage biafraud which is made to collocate with monkey metaphorically represents the Biafrans negatively as the idioms which revolve around monkey usually connote playing tricks and being dishonest. Here, the writer has combined the tenets of call the other derogatory names and ridicule the other with 
Ajayi \& Bamgbose: Ideologies and Impoliteness Strategies in Online Ethno-Religious

Conflict Among Nigerians

negative impoliteness strategies to attack the faces of Biafran agitators.

\section{Example 4}

This segment analyses posts/reactions on the Yoruba-Hausa clash in Ile-Ife. The researchers randomly selected three posts which are ideologically significant for this section.

\section{Excerpt 21}

RIP to the dead. If you criticize the excesses of these northerners now, yorubas will be the first to come for your head and call it "hate speech"

\section{Excerpt 22}

We said it, but they didn't listen

\section{Excerpt 23}

am just a bini boy observing the fight from Benin City. Uniben to be precise.abegosazee bring that binoculars make we check the people when involve for the fight first before we go track Cynthia for hall 1 then from there we go enter class. OooK. na them them. tinubu boys vsbuhari boys

The three posts above (21-23) have a similar ideological pattern, especially with regard to how the relationship between the Yoruba and Hausa of Nigeria is conceived by other tribes of the country. The us-them dichotomy here appears to be separately framed as the Yoruba and Hausa are jointly constructed as a political force or entity against the other ethnic groups in the country.

In Excerpt 21, you is metaphorically captured as a smaller and ideologically different force from the purportedly strong force, which is made up mainly of the Hausa and Yoruba who will always form a political alliance with the former. The Yoruba and Hausa are conceived by majority of the other tribes as a single political force in the Nigerian polity. This ideological stance is made clearer in Excerpt 22 which aptly depicts the us-them dichotomy. We is used to represent the smaller ideological force aside the Hausa-Yoruba camp and they represents the Yoruba. The discursive move of implication helps understand the post as an implicit blame on the Yoruba for their allegiance to the Hausa, who in turn have dealt with them (the Yoruba) in the YorubaHausa crisis in Ife, Osun State. In Excerpt 23, the writer metaphorically refers to himself as just a bini boy with the implication of expressing delight in watching the 'super powers' collide. The expression na them them 'it is them against them' further confirms the ideological construction of the Hausa and Yoruba as a single political force in the Nigerian political system. The final confirmation of this ideological grouping is the reference made to two strong political personalities among the Yoruba and the Hausa, Tinubu and Buhari, respectively. 


\section{General Discussion and Findings}

A combination of van Dijk's CDA and Culpeper's impoliteness theory for analysis in this study helps reveal certain ideological and identity stances in the issues of national concern that have been selected for analysis in this study. This study finds out that issues that border on religion and religious leaders are of national interest in the Nigerian society as they take the attention of both those in the ruling class and those that are ruled. It is also realised in the study that religious issues are offshoots of political matters and happenings in the country. This was made evident as the excerpts analysed on the Apostle Suleman's alleged sex scandal all tilt towards political affiliation and both the political figure that commented and other citizens who reacted all employ the issue as a political tact to either ideologically represent one party as being good or another as being bad.

It is also found in the data analysis that ethno-religious crisis in Nigeria boils down mainly on issues of sectional killing and insecurity. The killings, especially in the Northern part of the country, have constructed an antagonistic block between the faithful of the two major religions, Islam and Christianity, in the country. Excerpts analysed in the data show that the Christians have come to accept Islam as a violent religion which supports indiscriminate killing of people (particularly non-Muslims). There are also other excerpts showing efforts on the part of Muslims to differentiate Islam as a religion of peace from Muslims, who can be deficient as human beings. There is clearly an appeal to people not to see Islam in the light of the malicious attitude of some Muslims.

The third segment of the data which centres on a Biafran agitator for self-determination, Nnamdi Kanu, reveals a clear dichotomy and different ideological stances on the secession move of the Nigerian Easterners. The agitation coming from the supporters of Nnamdi Kanu, as evident in our data presentation and analysis, do not only show their love for him but also their optimism about the realisation of the Biafran State. There is also the construction of Nigeria and her people in a negative sense by the Biafrans, showing a clear diversity within the political entity called Nigeria. There is also a pessimistic view from Nigerians on the Biafran agitation, constructing the move and effort as not just being an unrealistic one but also one championed by 'talkers' rather than 'doers'.

The study also shows that the Hausa and Yoruba in Nigeria are ideologically conceived as a political force against the other tribes in the country. The posts analysed show that the Yoruba are conceived by the other tribes as loyalists to the Hausa on national issues. There is, therefore, an implicit blame or mockery on the Yoruba from non-Yoruba and non-Hausa ethnic groups for the massacre suffered in the hands of the Hausa in the Ife 
crisis.

\section{Conclusion}

This paper studies online ethno-religious conflict in Nigeria within the ambits of van Dijk's critical discourse analysis and Culpeper impoliteness theory. The combination of the theories helps reveal how linguistic tools are employed by different groups, ethnic, political and religious, for instance, in Nigeria to construct identities and perception about others, as well as ideologies in four events of national interest in the country. These events are the recent Apostle Suleman's alleged sex scandal which generated the slogan 'I stand with Apostle Suleman' on the social media, with a Canadian-based female musician, the Southern Kaduna killing in the North, the Yoruba-Hausa crisis in Ile Ife and issues surrounding the arrest, detention and the clamour for the release of Nnamdi Kanu, a force to reckon with in the agitation for the creation of Biafra by the Igbo people in the country, all in 2017. The study which realises different ideological stances across these issues submits that issues of national interest can be well understood through an investigation of discursive patterns in online news and the reactions they generate. The study thus concludes online ethno-religious conflict has a lot of implications for the continued existence of Nigeria as a united state, hence there is a need for all involved in the 'Nigeria Project' to fashion out peaceful ways of ensuring ethno-religious matters in the country are carefully managed so that they do not degenerate into an intractable situation.

\section{References}

Adetoye, Dele., and Omilusi Opeyemi. M, 2015. Ethno-religious conflicts and democracy in Nigeria. Global Journal of Arts Humanities and Social Sciences, $3(1)$, pp. 51-58.

Ajayi, Adeyinka T., and Buhari, Lateef O., 2014. Methods of conflict resolution in African traditional society, African Research Review, 8(2), pp. 138-157.

Ayantayo, J. Kehinde, 2005. Sociological examination of inter-religious conflict in Africa. In: Albert. I. Olawale (ed.), Perspectives on peace and conflict in Africa, Ibadan: John Archers Publishers, pp. 55-64

Brown, Penelope and Levinson, Stephen, 1987. Politeness: some universals in language usage. Cambridge: Cambridge University Press.

Coser, Lewis A. 1956. The functions of social conflict. New York: Free Press.

Crozier, David, and Blench, Roger, 1992. An index of Nigerian languages. Texas and Abuja: SIL and the NERDC.

Culpeper, Jacob, 2011. Impoliteness - using language to cause offence. Cambridge: University Press.

Culpeper, Jacob, 2008. Reflections on impoliteness, relational work and power: In

Derek Bousfield and Miriam Locher, eds., Impoliteness in Language - Studies on its 
Interplay with Power and Practice. Berlin: Mouton de Gruyter, pp. 17- 44.

Culpeper, Jacob, 1996. Towards an anatomy of impoliteness. Journal of Pragmatics, 25, pp. 349- 367.

Egbokhare, Francis, 2004. Language and Politics in Nigeria: In Kola Owolabi and Dasylva Ademola, eds. Forms and functions of English and indigenous languages in Nigeria. A Festschrift in Honour of Ayo Banjo. Ibadan: Group Publishers, pp. 507-522.

Ethnologue Language of the World, 2017, accessed 28. 3. 2017 on https://www.ethnologue.com/country/NG

Fawole, Oluwafemi A., and Bello, M. L. 2011.The impact of ethno-religious conflict on Nigerian Federalism. International NGO Journal, 6(10), pp. 211-218.

Idahosa, Osaretin, 2013. Ethno-religious conflict and peace building in Nigeria: the case of Jos, Plateau State. Academic Journal of Interdisciplinary Studies, 2(1), 349-360.

Jega, Attahiru, 2002. Tackling Ethno-Religious Conflict in Nigeria. The Nigerian Social Scientist, 5(2), 35-39.

Kuntsi, Piia, 2012. Politeness and impoliteness strategies used by lawyers in the 'Dover Trial' -A Case Study. An M.A. Thesis presented at the English Department, University of Eastern Finland, Finland.

Locher, Miriam A \& Bousfield, Derek, 2008. Impoliteness and power in language. In M. A. Locher and D. Bousfied, eds. Impoliteness in Language. Berlin Mouton de Gruyter, pp. 1-16

Mills, Sara, 2003.Gender and politeness. Cambridge: Cambridge University Press.

Nairaland, 2017. Yoruba-Hausa clash in Ile Ife, accessed 3.3.2017 on http://www.nairaland.com/3670783/yoruba-hausa-clash-ile-ife-5.

Osaghae, Eghosa E. 2011. The crippled giant: Nigeria since independence. Ibadan: John Archers Publishers.

Rashidi, Nasser, and Souzandehfar, Marzieh, 2010. A critical discourse analysis of the debates between Republicans and Democrats over the continuation of war in Iraq. The Journal of Linguistic and Intercultural Education (JoLIE), 3, 55-82.

Sahara Reporters, 2017, March 15. I stand with Buhari, accessed 5.5.17 on http://saharareporters.com/2017/03/15/i-stand-apostle-suleman-fayose-says.

Sule, Noah. R. 2012. Ethno-religious conflicts, mass media and national development: The Northern Nigeria experience. A PhD thesis in the Department of Religion and Philosophy, Faculty of Arts, University of Jos.

Terkourafi, Marina, 2008. Toward unified theory of politeness, impoliteness and rudeness: In Bousfield, Derek and Locher Miriam, eds. Impoliteness in language - studies on its interplay with power and practice. Berlin: Mouton de Gruyter, pp.18-45

Weber, Max, 1971. Max Weber on race and society (Trans.). Social Research, 38, 3041.

van Dijk Teun, 2004. Politics, Ideology and Discourse, accessed 10.10.2014 on 
Ajayi \& Bamgbose: Ideologies and Impoliteness Strategies in Online Ethno-Religious Conflict Among Nigerians

http://www.discourse-in-society.org/teun.html

Reisigl, Martin, and Wodak, Ruth. 2009. The discourse-historical approach. In R.

Wodak and M. Meyer, eds. Methods of critical discourse analysis (2nd ed), pp. London, UK: Sage, 87-121

Vanguard Nigeria, 2017. Kaduna killings.Vanguard Nigeria, accessed 20.3.2017 on http://www.vanguardngr.com/2017/01/un-wades-s- kaduna-killings-canreplies-council-imams-youre-hypocrites/

Vanguard Nigeria, 2017. IPOB warns contnued detention of Nnamdi Kanu. Vanguard Nigeria, accessed 5.5.2017 on http://www.vanguardngr.com/2017/02/ipobwarns- continued-detention-nnamdi- kanu/. 